\title{
Relation of Occupational Ethics Patterns and Staffs' Commitment of Social Security Organization of Markazi Province in Iran
}

\author{
${ }^{1}$ Zeinolabedin amini sabegh, ${ }^{2}$ Sirius tadbiri, ${ }^{3}$ Maryam mirjani \\ ${ }^{1,2}$ Departmen ${ }^{t}$ of Public management, Science and Research branch, Islamic Azad University, Saveh, Iran \\ ${ }^{3}$ Student of Public management, Science and Research branch, Islamic Azad University, Saveh, Iran.
}

\begin{abstract}
This study aims at representing the results of study conducted in Markazi province of Iran. In this study four patterns of occupational ethic (morals) is considered and their relation with organizational commitment of staffs of Social Security Organization is investigated. Subjects are 152 staffs of Social Security Organization in year 2013 that they are selected base on the Morgan sampling chart. Questionnaire is used as tool for gathering data that $0.90 \%$ reliability is obtained. The research method is measuring-descriptive method and descriptive statistic, Pearson's correlation inferential test and Freedman's test are used to analysis the data. In addition to introducing the methodology of research, the obtained results that indicate there is relation between the every patterns of occupational ethic and organizational commitment of staffs are represented here.
\end{abstract}

Keywords: staffs' relational behavior, interpersonal pattern, occupational ethic- based management, respect to staffs' rights, organizational commitment.

\section{Introduction}

Occupational morals are known as essential for enterprises so that it is considered as one of competitive advantages. Nowadays, ethical intelligence and training it to staffs of organizations is considered in business. In this respect it is said "training the occupational ethic increases the organizational commitment of staffs".

Since business combined with information and communication technology has made the competition implicate, the values, expectations and human relations call for a special management. Some scholars believe that "prevalence and training the occupational ethics in business results in organizational successes and facilitating management of competitive market and they have recommended developing ethics charter. Undoubtedly, enterprises and organizations have to follow and consider ethics in their activities. Each enterprise regard to its economic objectives and structure have to include and consider ethics (morals) in its activities. One scientist recommended four patterns of ethic: relational behavior pattern, strategic management pattern, regard and respect to people rights pattern, teaching occupational ethic pattern. What causes to optimize and improve the moral behavior of staffs into and outside the organization and individuals depends on mainly to several factors. In organization the organizational management, management and policies internally and economic and social factors externally and in individual level, personality can affect on moral behaviors of staffs. Research findings indicate that "to the extent that an organization or enterprise excludes these factors, occupational morals will be at risk".

\section{Problem Statement}

The definition of ethic in theory is "responsibility for people rights". This moral responsibility for self and other people is present in personal life, activities, occupation, into and outside the society. It is obvious that everyone first should experience the moral responsibility in his/her personal life and undertake it and then undertake moral responsibility in his/her occupational life. Such person can pay attention to moral responsibility in the society.

In some enterprises and companies such as banks and insurance companies, following and considering occupational ethics is much more essential than others because of their continuing relations with clients and providing interests, profit making and added value. Thus they encourage their staffs for obligation and responsibility. Social security organization is one of the enterprises requires these moral patterns because it delivers vast services and has many clients. In social security organization it was observed that the occupational ethics is less respected for various descriptions of staffs' tasks and duties and great referring of clients during the day and it is resulted in conflicts between staffs and clients. Thus it is believed that occupational commitment is undertaken weakly in this organization. Implementing and respecting to the occupational ethic patterns are being investigated to decline or remove the mentioned problem. Researcher intends to investigate four elements of occupational ethic which can be encouraged in this organization and increase the staffs' commitment. In fact, the variables that are to be measured and four elements of occupational ethics that the relation among them is investigated are: 1- relational behavior of staffs 2- training occupational morals 3- management approach based 
on occupational morals 4- respect to staffs' rights and staffs' commitment. The researcher is going to know whether there is relation between occupational morals patterns and organizational commitment of staffs.

\section{Hypothesizes}

- There is relation between the patterns of creating relational behavior of staffs and their commitment.

- There is relation between implementing the pattern of occupational training based on intrapersonal relation and staffs' commitment.

- There is relation between implementing the pattern of management based on occupational moral and staffs' commitment.

- $\quad$ There is relation between the pattern of respect to staffs' rights and their organizational commitment.

\section{Research Methodology and Hypothesizes Test}

Regard to purpose of study, it is applied study and since it investigates the relation between four patterns of occupational ethics and organizational commitment, its method is correlation.

Subjects are 152 staffs of social security organization in Markazi province of Iran in year 2013. Staffs questionnaire is employed as tool for gathering data and also library note is used to collect theoretical information. Reliability coefficient of questionnaire $\% 90$ is obtained before implementing research. Freedman and Pearson's test descriptive statistics is used to analysis data and SPSS software is applied to process and analysis data.

Hypothesis 1: there is relation between relational behavior pattern and organizational commitment.

Table1: Correlation Test between Relational Behavior Pattern and Organizational Commitment.

\begin{tabular}{|c|c|c|c|}
\hline $\begin{array}{c}\text { Organizational } \\
\text { commitment }\end{array}$ & $\begin{array}{c}\text { Relational behavior } \\
\text { pattern }\end{array}$ & parameter & \multirow{2}{*}{$\begin{array}{l}\text { variable } \\
\text { pattern }\end{array}$} \\
\hline 0.60 & 1 & Pearson's correlation Coefficient & Meaningful level \\
\hline- & 0.046 & Pearson's Correlation coefficient & $\begin{array}{l}\text { Organizational } \\
\text { commitment }\end{array}$ \\
\hline 1 & 0.60 & Meaningful level & \\
\hline
\end{tabular}

Correlation test in case of the relation between relational behavior pattern and organizational commitment indicated that the relation is confirmed at level $\mathrm{R}<0.05$. In fact, hypothesize 1 is accepted.

Hypothesize 2: there is relation between intrapersonal pattern and organizational commitment.

Table 2: Correlation Test between Intrapersonal Pattern and Organizational Commitment

\begin{tabular}{|c|c|c|c|}
\hline $\begin{array}{c}\text { Organizational } \\
\text { commitment }\end{array}$ & Intrapersonal pattern & parameter & variable \\
\hline 0.521 & 1 & Pearson's correlation coefficient & Intrapersonal pattern \\
\hline- & 0.007 & Meaningful level & \\
\hline 1 & 0.521 & Pearson's correlation coefficient & $\begin{array}{c}\text { Organizational } \\
\text { commitment }\end{array}$ \\
\hline 0.007 & - & Meaningful level & \\
\hline
\end{tabular}

Taken correlation test in case of relation between intrapersonal pattern and staffs' commitment indicated that the relation is confirmed at level $\mathrm{P}<0.05$. Hypothesis 2 is accepted.

Hypothesis 3: there is relation between management pattern and organizational commitment.

Table 3: Correlation Test between Management Pattern and Organizational Commitment

\begin{tabular}{|c|c|c|c|}
\hline $\begin{array}{c}\text { Organizational } \\
\text { commitment }\end{array}$ & Management pattern & parameter & variable \\
\hline 0.176 & 1 & Pearson's correlation coefficient & \\
\hline- & 0.030 & Meaningful level & Organizational \\
commitment \\
\hline 1 & 0.176 & Pearson's correlation coefficient & \\
\hline
\end{tabular}

Correlation test in case of relation between management pattern based on occupational morals and staffs' commitment indicated that this relation is confirmed at level $\mathrm{P}<0.05$. As matter of fact, hypothesis 3 is accepted.

Hypothesis 4: there is relation between the pattern of respect to staffs' rights and organizational commitment. 
Table 4: Correlation Test between Pattern of Respect to Staffs' rights and Organizational Commitment

\begin{tabular}{|c|c|l|l|}
\hline $\begin{array}{c}\text { Organizational } \\
\text { commitment }\end{array}$ & $\begin{array}{l}\text { Pattern of respect to } \\
\text { staffs' rights }\end{array}$ & Parameter & variable \\
\hline 0.478 & 1 & Pearson's correlation coefficient & $\begin{array}{l}\text { Pattern of respect to } \\
\text { staffs' rights }\end{array}$ \\
\hline- & 0.00 & Meaningful level & $\begin{array}{l}\text { Organizational } \\
\text { commitment }\end{array}$ \\
\hline 1 & 0.478 & Pearson's correlation coefficient \\
\hline 0.00 & - & Meaningful level & . \\
\hline
\end{tabular}

Taken correlation test in case of relation between pattern of respect to staffs' rights and organizational commitment indicated that the relation is confirmed at level $\mathrm{P}<0.05$. In fact, hypothesis 4 is accepted.

\section{Conclusion}

Regard to obtained results and the relation between moral patterns and organizational commitment, Freedman's test data was analyzed and the priorities of moral patterns were recognized. Priorities are respectively: 1- pattern o respect to staffs' rights 2- pattern based on intrapersonal relation 3-pattern of creating relational behavior in staffs 4 - pattern of management based on occupational morals

Although in this study the patterns are less compared and their priorities are considered, this study indicates that moral patterns are differently followed. Finding indicates that the function of every occupational moral pattern is various individually and organizationally. This function can be studied in future.

Occupational morals have different and effective functions and affects in trade market, enterprises and organizations. The organizations follow and respect ethics and moral patterns have staffs undertake responsibility and committed themselves to do their tasks and duties. Their staffs are accountable and have good relations with the clients. No parallel works and waste time is observed in these organizations and the staffs' relation in the organization is along with responsibility sense.

Patterns of occupational morals that are investigated in this study affect on organization effectiveness and productivity and customer satisfaction. Each pattern considers special dimension of human relations. Organizations regard to their tasks and operation nature consider one of the occupational moral patterns and set the ethics charter according it. Indeed all organizations require occupational moral pattern proportional with themselves and there is no organization without need it. Even organizations employ the high and the most advanced modern technology such as communication and information technology require following and respecting occupational morals specific to their organization to do their activities. Globally, following and respecting to occupational morals is considered a competitive advantage. A company, for example oblige itself to have services after sale, absolutely recognizes that it causes to attract customer, capture market and ability to take competitive advantage and added value. Thus respect and follow occupational ethics pattern should be respected and followed for its materiality, cultural and spiritual benefits and enterprises without respect it will be at great risk of damages.

\section{Reference}

[1]. Cooke, R .A. (1993).”Measuring Normative Beliefs and shared Behavioral Expectations in organizations: The Reliability and validity psychological Reports pp.72-83.

[2]. Mathieu, J.E.(1995)."A review and meta-analysis of the antecedents, correlates and consences of organizational commitment."Psychologicd Balletin, vol, 108, NO.2.PP:171-194.

[3]. Bamber, E.M.(2001)."Big 5 Auditors” Professional and organizational Identification university of Georgia, School of Accunting, pp.1-70.

[4]. Hackett, R.D.(2001).”Understanding the links Between work-Commitment constructs,” Journal of vocational Behavior, NO,58 pp:392-409.

[5]. Rahman.N.M. (2002)."Commitment to organization versus commitment to profession: Conflict or Compatibility?" Journal pengurusan, vol. 21 .pp:77-92.

[6]. Tsai. K. \& Wang, J. (2004).” The R \&D Performance in Taiwan's Electronic Industry....”,R \& D Management, vol 34, NO.2.pp: 179-189.

[7]. Foote, D. A. and Tang. T. (2008). Job satisfaction and organizational citizenship behavior (OCB): Does team commitment make a difference in self- directed teams? Management Decision vol 46. Pp 933-947.

[8]. Toll, M .k. (2006) An examination of the relationships between perceived procedural and distributive justice, job satisfaction and organizational citizenship Behavior Master of science thesis. Emporia: A study of the university. 